\author{
СА. Д. БЕДЕНЮК, В. В. МАЛЬОВАНИЙ, Л. Є. ВІЙТОВИЧ \\ ДВН3 “Тернопільський державний медичний університет імені І. Я. Горбачевського МОз України”
}

\title{
Гострі абсцеси легень та їх ускладнення: особливості перебігу та лікувальна тактика
}

\begin{abstract}
Мета роботи: підвищити ефективність комплексного лікування хворих на гострий абсцес легень.
Матеріали і методи. На базі відділення торакальної хірургії Тернопільської університетської лікарні за період 2014-2019 рр. проліковано 68 хворих із гострим абсцесом легень віком від 20 до 74 років.

Результати досліджень та їх обговорення. У лікуванні хворих використовували комплекс заходів, який включав антибактеріальну терапію, забезпечення дренажної функції бронхів, дезінтоксикацію та корекцію метаболічних порушень. За останні роки все частіше зустрічались тяжкі форми гнійних захворювань, які нерідко ускладнювались піопневмотораксом (у 18 хворих), емпіємою плеври (у 15 хворих), при яких проводилася пункція плевральної порожнини та дренування за Бюлау з подальшими санаціями антисептиками (діоксидин, хлоргексидин, декасан) тричі на день та активною аспірацією вмісту. При виникненні кровохаркання використовували препарати транексамової кислоти з гемостатичною метою. При арозивних кровотечах виконували ургентне операційне втручання (верхня лобектомія справа - у 2 пацієнтів). Тому перспективою подальших досліджень буде впровадження рентгенендоваскулярних методів зупинки арозивних кровотеч шляхом емболізації бронхіальних артерій, що надасть можливість стабілізувати стан хворого та підготувати до оперативного втручання, тим самим покращити прогноз лікування. Для покращення результатів лікування гострих абсцесів легень необхідний комплексний підхід з використанням сучасних консервативних та хірургічних методів.
\end{abstract}

Ключові слова: гострий абсцес легень; ускладнення; лікування.

Постановка проблеми і аналіз останніх досліджень та публікацій. Незважаючи на впровадження нових методів консервативного та операційного лікування із застосуванням антибактеріальних, дезінтоксикаційних та імунокоригуючих засобів, кількість хворих на гострий абсцес легень не має тенденції до зменшення, а клінічний перебіг, розвиток ускладнень та кінцевий результат терапії часто $є$ непередбачуваний $[1,3,4]$. Зростає рівень захворюваності серед населення працездатного віку. При цьому значно збільшується кількість ускладнених форм перебігу цього захворювання (кровотеча, емпієма плеври, піопневмоторакс, сепсис і бронхіальні нориці) до 50-60 \%, а летальність сягає 7-20 \% [5].

Мета роботы: підвищити ефективність комплексного лікування хворих на гострий абсцес легень.

Матеріали і методи. На базі відділення торакальної хірургії Тернопільської університетської лікарні за період 2014-2019 рр. проліковано 68 хворих з гострим абсцесом легень віком від 20 до 74 років, середній вік 52,4 року. Спостерігалась значна різниця статі пацієнтів - 12 жінок та 56 чоловіків. Ці дані пояснюються більш шкідливими умовами праці чоловіків, зловживанням алкоголем, курінням. Частіше патологічний процес розташовувався справа у 42 пацієнтів, зліва у 26. Здельшого причинами абсцесу легень були позагоспітальна пневмонія - 38 пацієнтів, аспіра- ція шлункового вмісту - 14 пацієнтів, перенесені травми - 8 пацієнтів, інші - 8 пацієнтів.

Розглядаючи терміни надходження хворих із гострими абсцесами легень в клініку, слід зазначити, що в строки до одного тижня в клініку надійшли 42 хворі (61,8 \%). Через два тижні після початку утворення абсцесу в клініку госпіталізовано 26 (38,2 \%) осіб, що пов'язано із самолікуванням. Стертість клінічної картини, пізні терміни діагностики та госпіталізації хворих у спеціалізовані відділеннях створюють всі умови для переходу гострих абсцесів у хронічні.

Найбільш інформативним методом діагностики абсцесів легень $€$ комп'ютерна томографія [6], яку виконували при госпіталізації пацієнта та через 2-3 тижні лікування. Рентгенографію органів грудної клітини виконували кожні 10 днів для контролю ефективності терапії. Всім хворим проводили фібробронхоскопію.

За даними мікробіологічного дослідження мокротиння, C. albicans, виявлено у 44 \% хворих, K.pneumoniae, P.aeruginisa, E.coli, B.catarralis y 14,4 \%, 6,5 \%, 5,3 \%, 4,7 \% пацієнтів відповідно. Enterobacter spp., Acinetobacter spp. виявляли у мокротинні хворих у поодиноких випадках.

Результати досліджень та їх обговорення. У лікуванні хворих використовували комплекс заходів, який включав антибактеріальну терапію, забезпечення дренажної функції бронхів, дезінток- 
сикацію та корекцію метаболічних порушень. Антибактеріальну терапію проводили з урахуванням антибіотикограми та ступеня інтоксикації внутрішньовенним шляхом або ендолімфатично. Переважно використовували такі групи препаратів у різних комбінаціях: цефалоспорини III-IV покоління, напівсинтетичні пеніциліни, фторхінолони, аміноглікозиди, похідні імідазолу, в особливо тяжких випадках - карбапенеми. Для дезінтоксикації застосовували розчини електролітів, реосорбілакт. 3 метою максимальної евакуації гною з абсцесу проводили санаційні бронхоскопії з наступним ендобронхіальним введенням антибіотиків, антисептиків, протеолітичних ферментів. Кількість бронхоскопічних санацій складала в середньому від 2 до 6 на курс лікування. Також виконували мікротрахеостомію та вводили антисептики (декасан, діоксидин) через мікроіригатор у відповідний бронх тричі на день. Такі санації позитивно впливають на перебіг запального процесу і сприяють зменшенню запальних явищ слизової оболонки бронхів і покращенню евакуації мокротиння завдяки його розрідженню та додатковому впливу на патогенну мікрофлору. У 80 \% пацієнтів спостерігалась гіпопротеїнемія, корекцію якої здійснювали шляхом переливання свіжозамороженої плазми, альбуміну, суміші амінокислот. Пацієнтам, які знаходились у тяжкому стані, забезпечували ентеральне або парентеральне харчування збалансованими харчовими сумішами. При наявності тяжкої анемії переливали еритроцитарну масу. Виражений клінічний ефект при комплексному лікуванні отримували вже у перші дні лікування. Позитивна динаміка полягала у зниженні температури тіла та рівня інтоксикації, вільному відходженні гнійного харкотиння, швидкому очищенні гнійної порожнини. При контрольних рентгенологічних дослідженнях у більшості випадків спостерігали позитивну динаміку, яка характеризувалась зменшенням ділянки запальної перифокальної інфільтрації та зменшенням розмірів порожнини абсцесу.

Проте, за нашими спостереженнями, за останні роки все частіше зустрічались більш тяжкі форми гнійних захворювань, які нерідко ускладнювались піопневмотораксом (у 18 хворих), емпіємою плеври (у 15 хворих), що пов'язано із високою вірулентністю мікробної флори, а також неефективними догоспітальними методами консервативної терапії. Іншими грізними ускладненнями абсцесів легень були кровохаркання і кровотеча, що спостерігалися у 5 хворих, найчастіше на фоні алкоголізму та наркоманії.

При емпіємі плеври та піопневмотораксі проводилася пункція плевральної порожнини та дренування за Бюлау з подальшими санаціями антисептиками (діоксидин, хлоргексидин, декасан) тричі на день та активною аспірацією вмісту. При тяжкій інтоксикації використовували два дренажі та налагоджували промивну систему для безперервної санації фізіологічним розчином із додаванням антисептиків.

При виникненні кровохаркання використовували препарати транексамової кислоти з гемостатичною метою. При арозивних кровотечах виконували ургентне операційне втручання (верхня лобектомія справа у 2 пацієнтів). Незважаючи на проведене лікування за даний період у клініці померло 5 (7,3 \%) хворих. Серед причин смерті: прогресивна інтоксикація у двох хворих, легенева недостатність у 2 хворих, легенева кровотеча в одного хворого.

Тому перспективою подальших досліджень буде впровадження рентгенендоваскулярних методів зупинки арозивних кровотеч, шляхом емболізації бронхіальних артерій, що надасть можливість стабілізувати стан хворого та підготувати до операційного втручання, тим самим покращити прогноз лікування [2].

Висновки. Для покращення результатів лікування гострих абсцесів легень необхідна його правильна організація на ранніх стадіях захворювання: рання діагностика, своєчасна госпіталізація та адекватне лікування в терапевтичних стаціонарах. Комплексне лікування гострих абсцесів із використанням сучасних консервативних та хірургічних методів дозволяє отримати задовільні безпосередні результати, повне клінічне одужання і відновити працездатність даного контингенту хворих.

\section{СПИСОК ЛІТЕРАТУРИ}

1. Бакуменко А. В. Мікробіологічні особливості збудників, вилучених із мокроти хворих на гнійно-деструктивні ускладнення позалікарняної пневмонії / А. В. Бакуменко // Annals of Mechnikov Institute. - № 2. - 2014. - C. 44-48.

2. Бойко В. В. Бронхиальная ангиография и лечебная эмболизация бронхиальных артерий у больных с легочными

кровотечениями / В. В. Бойко, Ю. В. Авдосьев, А. В. Токарев // Врачебная практика. - 2006. - № 2. - С. 63-65.

3. Застосування ліпосомальних лікарських композицій у лікуванні гнійно-деструктивних захворювань легень / В. В. Бойко, Д. В. Мінухін, Л. Г. Тарасенко [та ін.] // Харківська хірургічна школа. - 2015. - № 1(70) . - С. 55-58. 
4. Мінухін Д. В. Інструментальна діагностика абсцесів легень / Д. В. Мінухін, Г. В. Гувріков, А. Ф. Асамбаєв // Харківська хірургічна школа. - 2008. - № 1 (28). - С. 77-79.

5. Митюк И. И. Гнойные деструктивные заболевания легких и их лечение / И. И. Митюк, В. М. Шостак, Абдулхаким

\section{REFERENCES}

1. Bakumenko, A.V. (2014). Mikrobiolohichni osoblyvosti zbudnykiv, vyluchenykh iz mokroty khvorykh na hniino-destruktyvni uskladnennia pozalikarnianoi pnevmonii [Microbiological features of pathogens isolated from sputum in patients with purulentdestructive complications of community-acquired pneumonia]. Annals of Mechnikov Institute, 2, 44-48 [in Ukrainian].

2. Boyko, V.V., Avdosyev, Yu.V., \& Tokarev, A.V. (2006). Bronkhialnaya angiografiya i lechebnaya embolizatsiya bronkhialnykh arteriy u bolnykh s legochnymy krovotecheniyamy [Bronchial angiography and healing embolization of bronchial arteries in patients with pulmonary hemorrhages]. Vrachebnaya praktika - Medical Practice, 2, 63-65 [in Russian].

3. Boiko, V.V., Minukhin, D.V., Tarasenko, L.H., Tokariev, A.V., \& Smolianyk, K.M. (2015). Zastosuvannia liposomalnykh likarskykh kompozytsii u likuvanni hniino-destruktyvnykh zakhvoriuvan lehen [Application of liposomal medicinal compositions in the treatment of purulent-destructive lung
Махъюб Мохаммед Аль Камали // Biomedical and biosocial anthropology. - 2008. - № 11. - C. 168-171.

6. Чурилін Р. Ю. Променева діагностика ускладненого перебігу гострих абсцесів легень / Р. Ю. Чурилін // Український радіологічний журнал. - 2011. - № 19. - С. 389-394.

diseases]. Kharkivska khirurhichna shkola - Kharkiv Surgical School, 1 (70), 55-58 [in Ukrainian].

4. Minukhin, D.V., Huvrikov, H.V., \& Asambayev, A.F. (2008). Instrumentalna diahnostyka abstsesiv lehen [Instrumental diagnostics of abscesses of the lungs]. Kharkivska khirurhichna shkola - Kharkiv Surgical School, 1 (28), 77-79 [in Ukrainian].

5. Mityuk, I.I., Shostak, V.M., Abdulkhakym Makhyub Mokhammed Al Kamaly (2008). Gnoynye destruktivnye zabolevaniya lehkikh i ikh lechenye [Purulent destructive diseases of the lungs and their treatment]. Biomedical and biosocial anthropology - Biomedical and Biosocial Anthropology, 11, 168171 [in Russian].

6. Churylin, R.Yu. (2011). Promeneva diahnostyka uskladnenoho perebihu hostrykh abstsesiv lehen [Radiation diagnosis of complicated course of acute abscesses of lungs]. Ukrainskyi radiolohichnyi zhurnal - Ukrainian Radiological Journal, 19, 389-394 [in Ukrainian].

Отримано 03.04.2019

Електронна адреса для листування: bedenyuk@tdmu.edu.ua

\section{A. D. BEDENYUK, V. V. MALOVANYY, L. E. VIYTOVYCH}

I. Horbachevsky Ternopil State Medical University

\section{ACUTE LUNG ABSCESS AND THEIR COMPLICATIONS: FEATURES OF COURSE AND TREATMENT}

The aim of the work: to increase the effectiveness of complex treatment for patients with acute lung abscess.

Materials and Methods. On the basis of the Department of Thoracic Surgery of the Ternopil University Hospital for the period of 2014-2019, 68 patients with acute abscess of lungs aged 20 to 74 years were treated.

Results and Discussion. In the treatment of patients, a set of measures was used that included antibacterial therapy, bronchial drainage function, detoxification and correction of metabolic disorders. In recent years, more and more frequent cases of more severe forms of purulent diseases that were often complicated by pyopneumothoraks (18 patients), empyema of pleura (in 15 patients), which was accompanied by puncture of the pleural cavity and drainage for Bulaow with further sanation with antiseptics (dioxidine, chlorhexidine, decasan) three times a day and active aspiration of the contents. In the event of hemoptysis, preparations of trannexamic acid with hemostatic purpose were used. In an arrosive bleeding, urgent surgical intervention was performed (upper lobectomy on the right in 2 patients).

Therefore, the prospect of further research will be the introduction of X-ray diffractometry techniques for stopping the arrosive bleeding, by embolizing the bronchial arteries, which will enable stabilize the patient's condition and prepare for surgery, thereby improving the outlook for treatment.

Key words: acute lung abscesses; complications; management. 


\author{
А. Д. БЕДЕНЮК, В. В. МАЛЕВАНЫЙ, Л. Е. ВИЙТОВИЧ
}

ГВУз “Тернопольский государственный медицинский университет имени И. Я. Горбачевского МОЗ Украины”

\title{
ОСТРЫЕ АБСЦЕССЫ .ЛЕГКИХ И ИХ ОС.ЛОНННИЯ: ОСОБЕННОСТИ ТЕЧЕНИЯ И ЛЕЧЕБНАЯ ТАКТИКА
}

Цель работы: повысить эффективность комплексного лечения больных с острым абсцессом легких.

Материалы и методы. На базе отделения торакальной хирургии Тернопольской университетской больницы за период 20142019 гг. пролечено 68 больных с острым абсцессом легких в возрасте от 20 до 74 лет.

Результаты исследований и их обсуждение. В лечении больных использовался комплекс мероприятий, включавший антибактериальную терапию, обеспечение дренажной функции бронхов, дезинтоксикацию и коррекцию метаболических нарушений. За последние годы все чаще встречались более тяжелые формы гнойных заболеваний, которые нередко усложнялись пиопневмотораксом (у 18 больных), эмпиемой плевры (у 15 больных), при которых проводилась пункция плевральной полости и дренирование по Бюлау с последующими санациями антисептиками (диоксидин, хлоргексидин, декасан) три раза в день и активной аспирацией содержимого.

При арозивних кровотечениях выполняли ургентное операционное вмешательство (верхняя лобэктомия справа у 2 пациентов). Поэтому перспективой дальнейших исследований будет внедрение рентгенэндоваскулярных методов остановки арозивных кровотечений путем эмболизации бронхиальных артерий, что позволит стабилизировать состояние больного и подготовить к оперативному вмешательству, тем самым улучшить прогноз лечения. Для улучшения результатов лечения острых абсцессов легких необходим комплексный подход с использованием современных консервативных и хирургических методов.

Ключевые слова: острый абсцесс легких; осложнения; лечение. 